\section{Antioxidant and Enzyme Inhibitory Constituents from Dactyladenia floribunda and Chemicals Transformations of Hennadiol}

\author{
Adjapmoh Essombo MF ${ }^{1,2^{*}}$, Takou Dieudonné $\mathbf{M}^{1}$, Mehreen Lateef ${ }^{3}$, Ali Muhammad $\mathrm{S}^{2}$, Wansi Jean $\mathrm{D}^{1}$, Mbaze Meva'a LL $^{1}$ and Kamdem Waffo AF ${ }^{1}$ \\ ${ }^{1}$ Department of Chemistry, Laboratory of Bioorganic, Analytic and Structural Chemical, University of Douala, PO Box 24157 Douala, Cameroon \\ ${ }^{2}$ HEJ Research Institute of Chemistry, University of Karachi, Karachi, Pakistan \\ ${ }^{3}$ Pharmaceutical Research Center, Pakistan Council of Scientific and Industrial Research Laboratories Complex, Karachi, Pakistan
}

*Corresponding author: Adjapmoh Essombo MF, Department of Chemistry, Laboratory of Bioorganic, Analytic and Structural Chemical, University of Douala, PO Box 24157 Douala, Cameroon, Tel: +237 696284 551; E-mail: adjany2005@yahoo.fr

Received date: June 02, 2017; Accepted date: June 25, 2017; Published date: July 15, 2017

Copyright: @ 2017 Adjapmoh Essombo MF, et al. This is an open-access article distributed under the terms of the Creative Commons Attribution License, which permits unrestricted use, distribution, and reproduction in any medium, provided the original author and source are credited.

\begin{abstract}
Phytochemical studies on Dactyladenia floribunda Welw furnished twelve known compounds including (1) tetracosanoic acid, (2) $\beta$-sitosterol, (3) lupeol, (4) betulinol, (5) betulinic acid, (6) hennadiol, (7) ursolic acid, (8) oleanolic acid, (9) $\beta$-sitosterol-3-O- $\beta$-D-glucoside, (10) hexane-1,2,3,4,5,6-hexol, (11) 4'-methoxy-5,6,7trihydroxyflavone and (12) 5,7,4',5'-tetrahydroxyflavonol. (6) Hennadiol was subjected to microwave assisted diacetylation and hydrogenolysis. The crude extracts and some of these compounds were tested for their antioxidant and enzyme inhibitory activities.
\end{abstract}

Keywords: Dactyladenia floribunda; Diacetylation; Hydrogenolysis; Antioxidant activities; Enzyme inhibitory activities

\section{Introduction}

In the course of our investigation of Cameroonian medicinal plants to discover bioactive compound, we have carried out phytochemical studies on Dactyladenia floribunda Welw; which is a small tree belonging to the family Chrysobalanaceae. This family comprises 18 genera and about 533 species represented by trees and shrubs growing in tropical and subtropical lowlands [1]. The investigations on certain genera of this family such as Parinari, Licania, Chrysobalanus resulted on the isolation and characterization of flavonoids, triterpenoids, steroids, and tannins [2-4]. However, no phytochemical or pharmacological studies have so far been carried out on any species of the genus Dactyladenia. In this paper, we report the isolation and identification of known compounds including fatty acid, steroids, triterpenes, sugar and flavonoids from the stems barks of the title plant. The chemical transformations were also carried out on one of the isolates compound namely (6) hennadiol. The antioxidant, lipoxygenase and urease inhibitory activities of the crude extract as well as isolated and synthesized compounds have been determined.

\section{Materials and Methods}

\section{General}

Melting points were determined on a Buchi M-560 melting point apparatus and are uncorrected. UV spectra were recorded on Evolution $300 \mathrm{BB}$, IR spectra were recorded on SHIMADZU, FTIR-8900 infrared spectrometer. Hydrogenolysis reaction were done in $50 \mathrm{~mL}$ RB flack with magnetic stirrer (MINI MAG STIRRER DBK-5058/7) and microwave radiation was applied using a domestic microwave oven (Kenstar Model MWO-9808). The ${ }^{1} \mathrm{H},{ }^{13} \mathrm{C}$ and $2 \mathrm{D}$ NMR spectra were measured on at $500 \mathrm{MHz}$ Bruker DRX spectrometer. The chemical shifts are expressed in ppm units relative to
TMS. The EIMS were recorded on a JEOL MS 600-I mass spectrometer and ESIMS on a QSTARXL mass spectrometer. Silica $\mathrm{GF}_{254}$ plates $(20$ $\times 20 \mathrm{~cm} ; 0.2 \mathrm{~mm}$, E. Merck) were used for TLC. Column chromatographic purification was carried out over silica gel (Kieselgel 60; 230-300 mesh). All the solvents were distilled before use. The compounds were detected using an UV-lamp and by spraying with ceric acid solution followed by heating.

\section{Plant material}

The fresh parts (blossom, leaves and stem barks) of Dactyladenia floribunda Welw, were collected in April 2014 from Djeufam-Bazou, locality in the West region of the Republic of Cameroon. Plant material was authenticated by Mr NANA Victor, Botanist at the National Herbarium of Yaounde-Cameroon, where a voucher specimen (21720 SRF/CAM) has been deposited.

\section{Extraction and isolation}

The air-dried plant material $(3.95 \mathrm{~kg})$ was ground, powdered macerated and extracted with methanol at room temperature for $72 \mathrm{~h}$ and filtered. The filtrate was evaporated under reduced pressure to afford $268.16 \mathrm{~g}$ of crude extract. The part of the crude extract (156.24 g) was chromatographed over normal-phase silica gel open column and eluted with hexane followed by mixtures of hexane/EtOAc and $\mathrm{EtOAc} / \mathrm{MeOH}$ in increasing order of polarity increasing proportions to obtain nine fractions (DF-I to DF-IX) according to their TLC profiles. The main fractions DF-I (70 g), DF-III (7.15 g) and DF-VII (22 g), were re-chromatographed on silica gel column to obtain compounds $(1-12)$

\section{Chemical transformations of (6) Hennadiol}

Mirowave assisted deacetylation: Acetylation play important role in the isolation and structure elucidation of terpernoids. Acetylation using pyridine and acetic anhydride has been conventionally used with satisfactory results. These but often suffer from the defect of long 
Citation: Adjapmoh Essombo MF, Takou Dieudonné M, Mehreen Lateef, Ali Muhammad S, Wansi Jean D,et al. (2017) Antioxidant and Enzyme Inhibitory Constituents from Dactyladenia floribunda and Chemicals Transformations of Hennadiol. Nat Prod Chem Res 5: 280. doi: $10.4172 / 2329-6836.1000280$

Page 2 of 4

reaction time period and poor yields. We have used a method using microwave radiation which reduces the reaction time period to seconds.

Microwave is now being used extensively to bring about quicker result in organic reactions $[5,6]$. Most of the reactions reported so far however involve relatively simple molecules. Our studies reveal that it is equally applicable to complex molecules like triterpenes. Microwave assisted acetylation of (6) Hennadiol are reported herein. No structural breakdown has been observed in any intake.

Hennadiol (6) (60 mg) was dissolved in pyridine (2 mL) and acetic anhydride $(0.4 \mathrm{~mL})$ was added. Microwave radiation at full intensity was applied for $120 \mathrm{sec}$ in $30 \mathrm{sec}$ intervals (Figure 1). After every $30 \mathrm{sec}$ a small quantity of the reaction mixture was removed and analysed by TLC. The spot corresponding to compound (6) disappeared completely between 90 and $120 \mathrm{sec}$. The reaction mixture was cooled and worked up by the usual procedure to yield 3,30-diacetoxy-lup-20(29)-ene (13) (56 $\mathrm{mg}$ ) as white amorphous powder. Its structure was identified by mass and NMR spectral data.

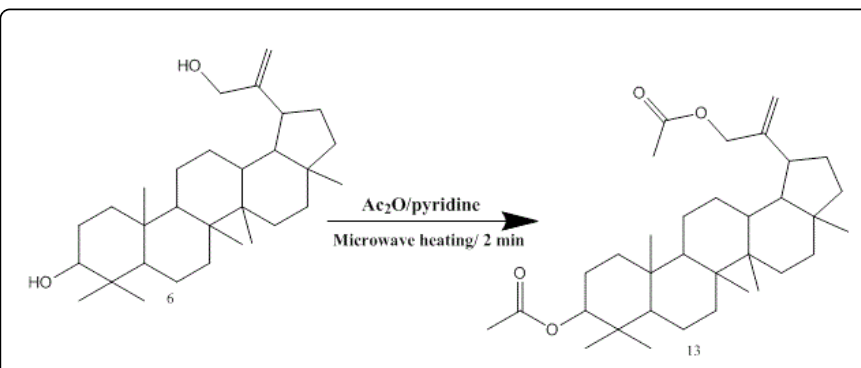

Figure 1: Diacetylating reaction of hennadiol (6).

Hydrogenolysis: Hennadiol (6) (50 mg) was dissolved in $\mathrm{CH}_{2} \mathrm{Cl}_{2}$ (5 $\mathrm{mL})$ and $\mathrm{MeOH}(2 \mathrm{~mL})$. After $15 \mathrm{~min}$ of agitation, 5\% palladium charcoal (5 mg) was added and hydrogen was passed under stirring at room temperature for $44 \mathrm{~h}$. The progress of the reaction was monitored by TLC every $5 \mathrm{~h}$. After 44 hours, the mixture was filtered and the residue was washed four times with $10 \mathrm{~mL}$ of $\mathrm{CH}_{2} \mathrm{Cl}_{2}$ : $\mathrm{MeOH}(9: 1)$. The TLC analysis indicated the presence of three compounds which were separated through column chromatography over silica gel eluting with hexane: ethyl acetate (99: 1) to obtain lupeol (3) (17 mg), hexane: ethyl acetate (97.5: 2.5$)$ to obtain 20-3 $\beta$-hydroxylupan-30-al (14) $(10$ $\mathrm{mg}$ ), and hexane: ethyl acetate (24: 1$)$ to obtain 30 norlupan-3 $\beta$-ol-20one (15) (12 mg).

\section{DPPH radical scavenging activity}

A serial dilution of the test fractions was made in either DMSO or methanol to obtain final concentrations of 500, 250, 150, 125, 62.5, $31.2,15.6$, and $7.8 \mu \mathrm{M}$. A $0.3 \mathrm{mM}$ solution of DPPH in ethanol was prepared and $90 \mu \mathrm{L}$ of this was added to each well of a 96 -well plate marked for control and test compounds. Then, $10 \mu \mathrm{L}$ of each of the concentrations of the compound was added to the particular well to start the reaction. The contents of the wells were mixed for a few sec and then the mixture was incubated for $30 \mathrm{~min}$ at $37^{\circ} \mathrm{C}$ and the absorbance measured at $\lambda 517$ by a micro titre plate reader (Spectra Max plus 384 Molecular devices USA). The assay was standardized using butylated hydroxyanisole (BHA) prior to testing the compounds. Percent radical scavenging activity was determined in comparison with methanol treated control and $\mathrm{IC}_{50}$ was calculated for each compound by EZ fit software (Perrella Software, USA) $[7,8]$.

$$
\% \mathrm{DPPH} \text { radical scanvenging effect }=\mathrm{Ac} \frac{A s}{\mathrm{Ac}} \times 100
$$

\section{Lipoxygenase inhibiting activity}

Lipoxygenase enzyme solution was prepared so that the enzyme concentration in reaction mixture was adjusted to give $130 \mathrm{U}$ per well. $160 \mu \mathrm{L}$ of $100 \mathrm{mM}$ sodium phosphate buffer ( $\mathrm{pH}$ 8.0) was added in each well of plate labeled as blank (B substrate and B enzyme), Control and Test. $10 \mu \mathrm{L}$ of test compound solution in methanol (of various concentrations 5-500 $\mu \mathrm{M}$ ) were added in each well labeled as test. 20 $\mu \mathrm{L}$ Lipoxygenase $(20 \mu \mathrm{L})$ (LOX) solution was added in each well including B (enzyme), control, test except B (substrate). The contents were mixed and incubated for $10 \mathrm{~min}$ at $25^{\circ} \mathrm{C}$. Substrate solution was flushed with nitrogen gas to avoid auto oxidation before adding to each well. The reaction was then initiated by the addition of $10 \mu \mathrm{L}$ substrate solution (linoleic acid, $0.5 \mathrm{mM}, 0.12 \% \mathrm{w} / \mathrm{v}$ tween 20 in ratio of $1: 2$ ) in each well except $\mathrm{B}$ (enzyme) and the absorbance was measured and recorded at $234 \mathrm{~nm}$. The concentration of the test compound that inhibited lipoxygenase activity by $50 \%\left(\mathrm{IC}_{50}\right.$ ) was determined by monitoring the effect of increasing concentrations of these compounds in the assays on the degree of inhibition. The $\mathrm{IC}_{50}$ values were calculated by means of EZ-Fit, Enzyme kinetics Program (Perrella Scientific In., Amherset, USA) [5,6].

\section{Urease assay and inhibition}

Reaction mixtures comprising $25 \mu \mathrm{L}$ of enzyme (Jack bean Urease) solution and $55 \mu \mathrm{L}$ of buffers containing $100 \mathrm{mM}$ urea were incubated with $5 \mu \mathrm{L}$ of test compounds ( $1 \mathrm{mM}$ concentration) at $30^{\circ} \mathrm{C}$ for $15 \mathrm{~min}$ in 96-well plates. Urease activity was determined by measuring ammonia production using the indophenol method as described by Weatherburn. Briefly, $45 \mu \mathrm{L}$ each of phenol reagent $(1 \% \mathrm{w} / \mathrm{v}$ phenol and $0.005 \% \mathrm{w} / \mathrm{v}$ sodium nitroprusside) and $70 \mu \mathrm{L}$ of alkali reagent $(0.5 \% \mathrm{w} / \mathrm{v} \mathrm{NaOH}$ and $0.1 \%$ active chloride $\mathrm{NaOCl})$ were added to each well. The increasing absorbance at $630 \mathrm{~nm}$ was measured after $50 \mathrm{~min}$, using a microplate reader (Molecular Device, USA). All reactions were performed in triplicate in a final volume of $200 \mu \mathrm{L}$. The results (change in absorbance per min) were processed by using SoftMax Pro software (Molecular Device, USA). All the assays were performed at $\mathrm{pH} 8.2$ $\left(0.01 \mathrm{M} \mathrm{K}_{2} \mathrm{HPO}_{4} \cdot 3 \mathrm{H}_{2} \mathrm{O}, 1 \mathrm{mM}\right.$ EDTA and $\left.0.01 \mathrm{M} \mathrm{LiCl}_{2}\right)$. Percentage inhibitions were calculated from the formula $100-\left(\mathrm{OD}_{\text {test well }} / \mathrm{OD}_{\text {control }}\right)$ $\times 100$. Thiourea was used as the standard inhibitor of urease.

\section{Results and Discussion}

The crude extract (150.16 g) was subjected to column chromatography over silica gel and eluted with hexane followed by mixtures of hexane/EtOAc and $\mathrm{EtOAc} / \mathrm{MeOH}$ in increasing order of polarity to obtain nine fractions (DF-I to DF-IX). The Fractions DF-I (70 g), was subjected to CC over silica gel $(300 \mathrm{~g}$, column: $100 \times 8 \mathrm{~cm})$ and eluted with hexane followed by hexane/ EtOAc (1:1) to yield six fractions DFI-a, DFI-b, DFI-c, DFI-d, DFI-e, DFI-f. Compound 1 (20 $\mathrm{mg}$ ) was obtained from fraction DFI-a, Compound 2 (200 mg) [9], was obtained from fraction DFI-b, Compound $3(8 \mathrm{mg})$ and compound 4 (15 mg) [10] was obtained from fraction DFI-d, Compound 5 (40 mg) [11] was obtained from fraction DFI-e and compound 6 (300 mg) [12] was obtained from fraction DFI-f. Fraction DF-III (7.15 g) was subjected to column chromatography (CC) over silica gel (300 g, 
Citation: Adjapmoh Essombo MF, Takou Dieudonné M, Mehreen Lateef, Ali Muhammad S, Wansi Jean D,et al. (2017) Antioxidant and Enzyme Inhibitory Constituents from Dactyladenia floribunda and Chemicals Transformations of Hennadiol. Nat Prod Chem Res 5: 280. doi:

column: $80 \times 4 \mathrm{~cm}$ ) using hexane followed by hexane/EtOAc (6: 4) to furnish compound 7 (12 mg) [4]. Compound 8 (17 mg) [9] and compound $9(100 \mathrm{mg})$ [13]. Compounds $10(30 \mathrm{mg}), 11(50 \mathrm{mg})$ and $12(64 \mathrm{mg})$ [14] were obtained from fraction DF-VII $(22 \mathrm{~g})$ after purification over CC using silica gel $(200 \mathrm{~g}$, column $(50 \times 4 \mathrm{~cm})$ eluting with $\mathrm{EtOAc} / \mathrm{MeOH}$ (9: 1). The structures of these compounds were established by their spectroscopic data and subsequent comparison with literature.

The pyridine solution of the compound (6) were treated with appropriate amount of acetic anhydride (as indicated in materials and methods section) and subjected to microwave treatment for sufficient time in 30 second intervals. After every 30 seconds a small portion of the reaction mixture was withdrawn and was analysed by TLC. All Conversions were completed with 2 to 4 doses of irradiation. Conventional acetylation was done with the same type of reaction mixtures by heating on a water-bath for one hour followed by keeping overnight. TLC indicated the presence of small amounts of unreacted compound in these reactions. Microwave assisted diacetylation of hennadiol afforded the corresponding diacetyl derivative (13) (56 mg) (Figures 1-4) while hydrogenolysis and subsequent separation of the resulting mixture by CC provided Lupeol (3) (17 mg) [4], compound (14) (10 mg) [15], and (15) (12 mg) [16] (Figures 2-4). All compounds obtained by chemical transformations were identified by examination of the ${ }^{1} \mathrm{H},{ }^{13} \mathrm{C}$ and $2 \mathrm{D}-\mathrm{NMR}$ along with MS data.

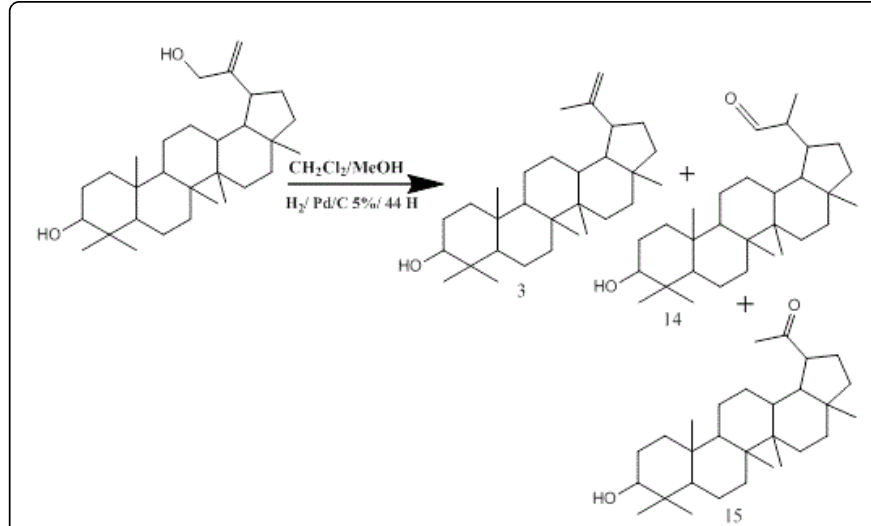

Figure 2: Structures of products obtained on hydrogenolysis of hennadiol (6).

The crude extracts of different parts of the title plant were screened for antioxidant and lipoxygenase inhibitory activity while compounds $2-7,10,14$ and 15 were subjected to antioxidant screening and urease inhibitory activity and the results are illustrated in Tables 1 and 2, respectively.

\begin{tabular}{|l|l|c|c|}
\hline S.No & Crude extract & Antioxidant Activity $(\mathbf{\%}$ at conc $\mathbf{5 0} \mathbf{\mu g} / \mathbf{1 0} \boldsymbol{\mu l})$ & Lipoxygenase Inhibition Activity IC $\mathbf{~}_{\mathbf{5 0}}(\boldsymbol{\mu M})$ \\
\hline 1 & Blossom & $97.7 \pm 0.70$ at $\mathbf{5 0} \boldsymbol{\mu g}$ & $68.2 \pm 0.12$ \\
\hline 2 & Leaves & $96.6 \pm 0.31$ & $60.4 \pm 0.76$ \\
\hline 3 & Stem barks & $57.7 \pm 0.12$ & $75.7 \pm 0.54$ \\
\hline 4 & BHA & $44.2 \pm 0.32$ & $22.6 \pm 0.17$ \\
\hline 5 & Bacelin & - & \\
\hline BHA: Butylated hydroxyanisole (standard of antioxidant) \\
Bacelin: (standard of lipoxygenase)
\end{tabular}

Table 1: Results of antioxidant and lipoxygenase inhibition activity of crude extract.

\begin{tabular}{|c|c|c|}
\hline Compound & Antioxidant Activity $\mathrm{IC}_{50}(\boldsymbol{\mu M})$ & Urease Inhibition Activity $\mathrm{IC}_{50}(\mu \mathrm{M})$ \\
\hline 2 & $<200$ & $20.4 \pm 0.76$ \\
\hline 3 & $65.3 \pm 0.41$ & Nil \\
\hline 4 & $31.4 \pm 0.33$ & Nil \\
\hline 5 & $43.1 \pm 0.82$ & Nil \\
\hline 6 & $28.5 \pm 0.08$ & Nil \\
\hline 7 & $16.7 \pm 0.64$ & $78.9 \pm 0.75$ \\
\hline 10 & $<200$ & $43.6 \pm 0.23$ \\
\hline 14 & $54.1 \pm 0.38$ & Nil \\
\hline 15 & $52.2 \pm 0.18$ & Nil \\
\hline $\mathrm{BHA}$ & $44.2 \pm 0.34$ & - \\
\hline
\end{tabular}


Citation: Adjapmoh Essombo MF, Takou Dieudonné M, Mehreen Lateef, Ali Muhammad S, Wansi Jean D,et al. (2017) Antioxidant and Enzyme Inhibitory Constituents from Dactyladenia floribunda and Chemicals Transformations of Hennadiol. Nat Prod Chem Res 5: 280. doi:

Page 4 of 4

\begin{tabular}{|l|l|c|}
\hline \multicolumn{1}{|c|}{ Thiourea } & $-1.9 \pm 0.32$ \\
\hline BHA: Butylated hydroxyanisole (standard of antioxidant) & 21.9 \\
Thiourea: (standard inhibitor of urease) & \\
\hline
\end{tabular}

Table 2: Results of antioxidant and urease inhibitory inhibition activity of pure isolates 2-7, 10, 14 and 15.
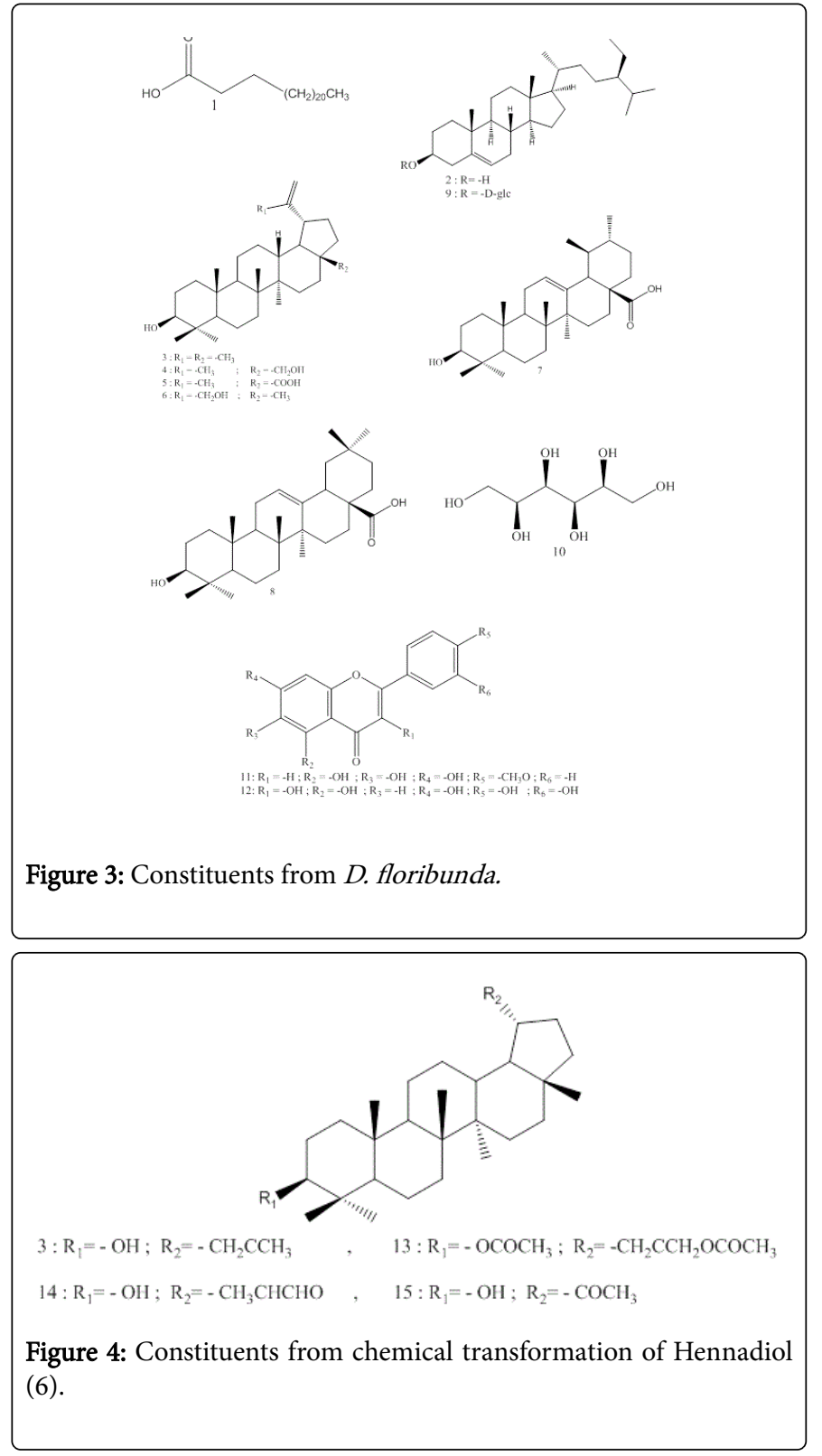

\section{Acknowledgment}

Authors are thankful to the International Canter for Chemical and Biological Sciences (ICCBS), University of Karachi, Pakistan for research facilities and Third World Academy of Sciences (TWAS), Italy for financial support under an ICCBS-TWAS Sandwich Program.

\section{Conflict of Interest}

The authors declare no conflict of interest.

\section{References}

1. Yakandawala D, Morton CM, Prance GT (2010) Phylogenetic relationships of the Chrysobalanaceae inferred from chloroplast, nuclear, and morphological data. Ann Missouri Bot Gard 97: 259-281.

2. Feitosa EA, Xavier HS, Randau KP (2012) Chrysobalanaceae: traditional uses, phytochemistry and pharmacology. Rev Bras Farmacogn 22: 1181-1186.

3. Castilho RO, Kaplan MAC (2008) Chemosystematics of the Rosiflorae. Braz J Biol 68: 633-640.

4. Castilho RO, Kaplan MAC (2008) Chemical agents of Licania tomentosa Benth. (Chrysobalanaceae). Quim Nova 31: 66-69.

5. Berian J, Giborreaup S, Le Feuvre A, Marchand C (1991) Organic Syntheses Under Microfields-Premier example activation specific on phase, homogeneous tetrahedron. Lett 32: 2363.

6. Mogilaiah K, Reddy NV, Rao RB (2001) Synthesis Of 2Aminonicotinaldehyde Hydrazones as Possible Antimicrobial Agents. Indian J Chem 40B: 717.

7. Ali S, Yasmeen S, Afza N, Malik A, Iqbal L, et al. (2009) Mutiniside, new antioxidant phenolic glucoside from Abutilion muticum. J Asian Nat Prod Research 11: 457-464.

8. Siddiq FF, Fatima II, Malik A, Afza N, Iqbal L, et al. (2012) Biologically active bergenin derivatives from Bergenia stracheyi. Chem Biodiver 9: 91-98.

9. Sanduja R, Alam M, Euler KL (1983) Contituents of Couepia paraensis. J Nat Prod 46: 149.

10. Chaturvedula VSP, Gao Z, Hecht SM, Jones SH, Kingston DGI (2003) A new acylated oleanane triterpenoid from Couepia polyandra that inhibits the lyase activity of DNA polymerase. J Nat Prod 66: 1463-1465.

11. Patocka J (2003) Biologically active pentacyclic triterpenes and their current medicine signification. J App Biomed 1: 7-12.

12. Van Kiem P, Van Minh C, Huong HT, Nam NH, Lee JJ, et al. (2004) Pentacyclic triterpenoids from Mallotus apelta. Arch Pharm Res 27: 1109-1113.

13. Bilia AR, Mendez J, Morelli I (1996) Phytochemical investigations of Licania Genus, Flavonoids and triterpenoids from Licania carii. Pharm Acta Helv 71: 191-197.

14. Coradin L, Giannasi DE, Prance GT (1985) Chemosystematic studies in the Chrysobalanaceae I. Flavo Parina Britto 37: 169-178.

15. Mutai C, Abatis D, Vagias C, Moreau D, Roussakis C, et al. (2007) Lupane triterpenoids from Acacia mellifera With Cytotoxic Activity. Molecules 12: 1035-1044.

16. Takeda Y, Fatope MO (1988) New phenolic glucosides from Lawsonia inermis. J Natu Prod 51: 725-729. 